\title{
ORNL AGR PIE Upgrades - FY08 Summary Report
}

\section{John D. Hunn, Robert N. Morris, and Charles A. Baldwin \\ August 2008}

This document has been reviewed and is determined to be APPROVED FOR PUBLIC RELEASE.

Name/Title: Leesa Laymance/ORNL TIO

Date: $\underline{5 / 14 / 2020}$

This report was prepared as an account of work sponsored by an agency of the United States Government. Neither the United States Government nor any agency thereof, or any of their employees, makes any warranty, expressed or implied, or assumes any legal liability or responsibility for any third party's use, or the results of such use, of any information, apparatus, product or process disclosed in this report, or represents that its use by such third party would not infringe privately owned rights. 


\section{DOCUMENT AVAILABILITY}

Reports produced after January 1, 1996, are generally available free via the U.S. Department of Energy (DOE) Information Bridge.

Web site http://www.osti.gov/bridge

Reports produced before January 1, 1996, may be purchased by members of the public from the following source.

National Technical Information Service

5285 Port Royal Road

Springfield, VA 22161

Telephone 703-605-6000 (1-800-553-6847)

TDD 703-487-4639

Fax 703-605-6900

E-mail info@ntis.fedworld.gov

Web site http://www.ntis.gov/support/ordernowabout.htm

Reports are available to DOE employees, DOE contractors, Energy Technology Data Exchange (ETDE) representatives, and International Nuclear Information System (INIS)

representatives from the following source.

Office of Scientific and Technical Information

P.O. Box 62

Oak Ridge, TN 37831

Telephone 865-576-8401

Fax 865-576-5728

E-mail reports@adonis.osti.gov

Web site http://www.osti.gov/contact.html

This report was prepared as an account of work sponsored by an agency of the United States Government. Neither the United States Government nor any agency thereof, nor any of their employees, makes any warranty, express or implied, or assumes any legal liability or responsibility for the accuracy, completeness, or usefulness of any information, apparatus, product, or process disclosed, or represents that its use would not infringe privately owned rights. Reference herein to any specific commercial product, process, or service by trade name, trademark, manufacturer, or otherwise, does not necessarily constitute or imply its endorsement, recommendation, or favoring by the United States Government or any agency thereof. The views and opinions of authors expressed herein do not necessarily state or reflect those of the United States Government or any agency thereof. 


\title{
ORNL AGR PIE Upgrades - FY08 Summary Report
}

\author{
John D. Hunn, Robert N. Morris, and Charles A. Baldwin \\ August 2008
}

\section{PIE Support (MPO-70085/SOW-5698)}

\section{Objectives}

FY08 objectives were for ORNL to support INL in the development of a PIE Plan for the AGR-1 test by providing technical input, analysis, and expertise to the drafting and review of the document. ORNL would also participate in various planning activities that are needed to support the NGNP PIE effort. This would include the evaluation of new PIE methods and preparation of evaluation reports as needed. This task also included working with INL staff in the development and implementation of existing PIE techniques as needed to ensure consistent experimental results. ORNL staff would also participate in general planning activities for the overall NGNP PIE effort, including schedule and scope planning for future AGR experiment PIE activities. This included considerations of the NGNP conceptual design and the implications this will have on the approach to PIE data collection for all of the AGR fuel experiments.

\section{FY08 Progress Summary}

The first part of this activity, supporting the draft AGR-1 PIE, was completed by a series of draft report reviews, informal discussions, conference calls, and e-mails with INL staff and the AGR Technical Coordination Team (TCT). PIE planning efforts have included an evaluation of the PIE techniques to be used as a function of the AGR-1 in-reactor fuel performance. Because the fuel is performing well, the early emphasis has shifted toward showing that the performance goals for the fuel are being met rather than concentrating on individual particle examination. Since proof of performance is crucial for the NGNP design and schedule, this focus on overall performance allows the program to vet the fuel (design) variants and show a connection with the best performing historical fuel. If the good fuel behavior continues, the NGNP conceptual design can be approached with a creditable fuel, supported by early PIE data.

Other support activities included the transfer of established PIE procedures from ORNL to INL to facilitate the development of consistent hardware and techniques at both laboratories. Also ORNL staff have interfaced with INL staff in the planning for putting into place the required equipment and capabilities to perform the tests outlined in the PIE plan. This includes the implementation of existing techniques as well as the development of new methods. Several upgrade tasks were identified for FY08 and FY09 in preparation for availability of AGR-1 irradiated fuel in FY10.

\section{Future Activities}

The AGR-1 PIE plan is expected to be issued soon by INL. This work has lead to a better understanding of the tools needed for the PIE task, the way to conduct it, and prioritization of the tests. We expect to further refine the PIE planning and necessary tools in the upcoming months. ORNL will also continue to provide support on general PIE activities. 


\section{Upgrade Optical Microscopy Capability (MPO-70089/SOW-5699)}

\section{Objectives}

This task involved the purchase and installation of a new metallograph in the Microscopy cubicle on the second floor of the ORNL Irradiated Fuels Examination Laboratory (Building 3525). The new metallograph will offer greater versatility in terms of magnification and optical microscopy techniques, greatly enhanced imaging capability, and its precision automated positioning will allow multiple images to be easily assembled into a collage with minimal operator effort. This will allow higher quality data collection, faster image collection, and more efficient data archiving. The new metallograph will ultimately be used to perform PIE optical microscopy on compact and particle cross-sections, to characterize kernel, coating, and compact matrix microstructures. The work scope for this task included purchase of the new metallograph and related hardware, completing the design for the system layout and in-cell mounting, fabrication of parts required for installation, software programming, installation of the system in the SEM cubicle, and final system testing.

\section{FY08 Progress Summary}

All interim milestones have been completed. A system was ordered in November, delivered in March, and bench testing was completed in May. The remote hotcell metallograph consists of a Leica DMI5000M inverted optical microscope base with motorized objective turret, zoom lens turret, illumination cube turret, differential interference contrast (DIC) prism turret, field and aperture diaphragm turrets, lamp power supply, and XYZ stage. A control box communicates with the various motorized accessories and stores the microscope settings. A PC computer sends commands to the control box and receives image data from a digital camera attached to one of the camera ports on the microscope. Leica Application Suite (LAS) software provides the graphical user interface (GUI).

Functionality of the microscope has been confirmed. The lamp and apertures were aligned. Parfocality and parcentricity were adjusted. Optimal settings for the field and aperture "diaphragms" (actually selectable fixed apertures) were identified for each objective. Optimal camera settings were identified. Each combination of objective and zoom lens was tested. A surface mirror was used to set the shading correction and the Multistep image tiling feature (used to image areas larger than the field of view) was demonstrated successfully. A custom stage insert was designed and manufactured to accept the standard 1.25" metallographic mounts used in the hotcell. The stage was leveled using set screws in the outer stage plate designed for this purpose. Three c-mount adapters for the digital camera were evaluated. In this evaluation, vignetting, field of view, magnification non-linearity, and resolution were measured. A separate report was generated with the details of this evaluation. A $0.70 x$ c-mount was selected. The image capture and microscope resolution meet expectations. A calibration procedure was decided on that will use a NIST traceable standard to establish the micron per pixel calibration for images captured for each combination of objective and zoom lens used. The calibration data can then be saved with each image.

Figure 1 shows the metallograph as it will be in the normal operating position against the right side of the cubicle and Figure 2 shows it in the cleaning and maintenance position in the center 
of the cubicle. Figure 3 shows the microscope on its sliding turntable, which will allow it to be moved from operating to maintenance position. The cubicle has a stainless steel liner and is shielded on the front, back, top, bottom, and right side by 8 -inches of steel plate. The left side is shielded by the 2 -foot thick concrete wall of the hot equipment storage cell. In the figures, the 2 red circles near the center represent the static locations of the left and right manipulators and the door/window of the cubicle is at the bottom of the figures. The penetration for the control cables needed for the metallograph is available on the back of the cubicle.

The SEM cubicle has been tented, opened, and wiped down. The shield plug in the right rear corner of the cubicle has been removed and the Building 3525 staff is currently in the process of designing a new plug. Measurements are being made on the old shield plug. Once the measurements are complete, a new plug will be designed and fabricated, wired, and tested as a unit with the metallograph.

\section{Future Activities}

Little additional work is required to complete installation of the metallograph into the cell. This is scheduled to occur in September, but there is some schedule risk due to conflicting Building 3525 priorities. Once in place, the system will be tested and the operating procedures finalized. No unusual operational or safety problems are anticipated.

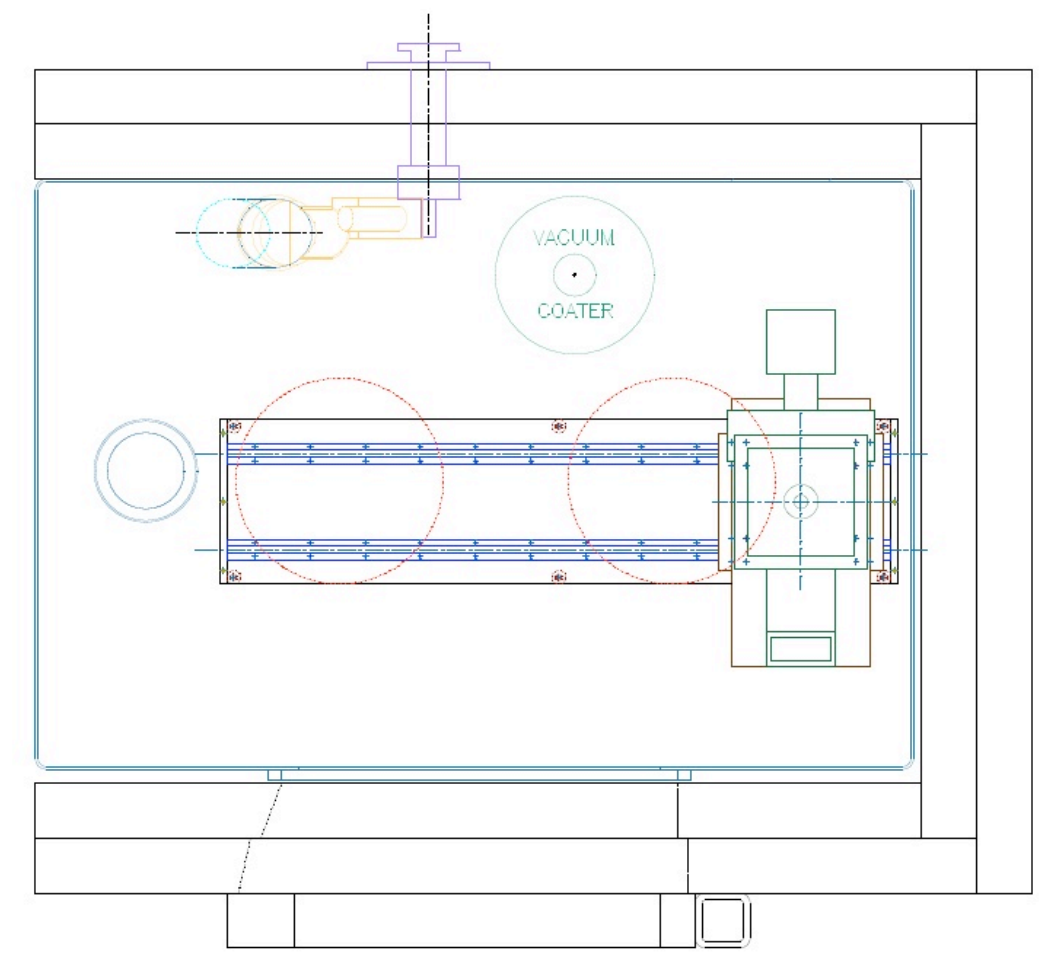

Figure 1. Top view of the SEM cubicle showing the rail table and metallograph in their normal operating positions. The 2 red circles represent the locations of the left and right manipulators. 


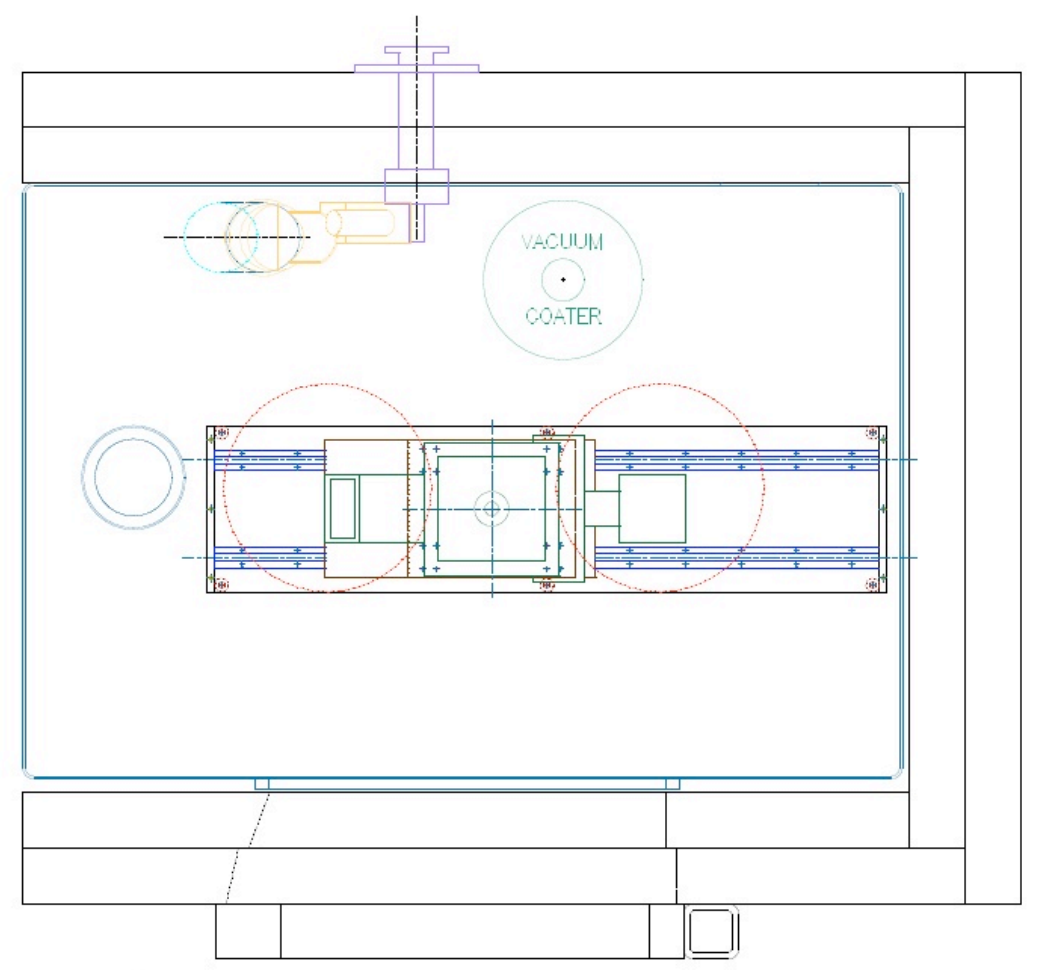

Figure 2. Top view of the SEM cubicle showing the metallograph in the cleaning and maintenance position in the center of the cubicle.

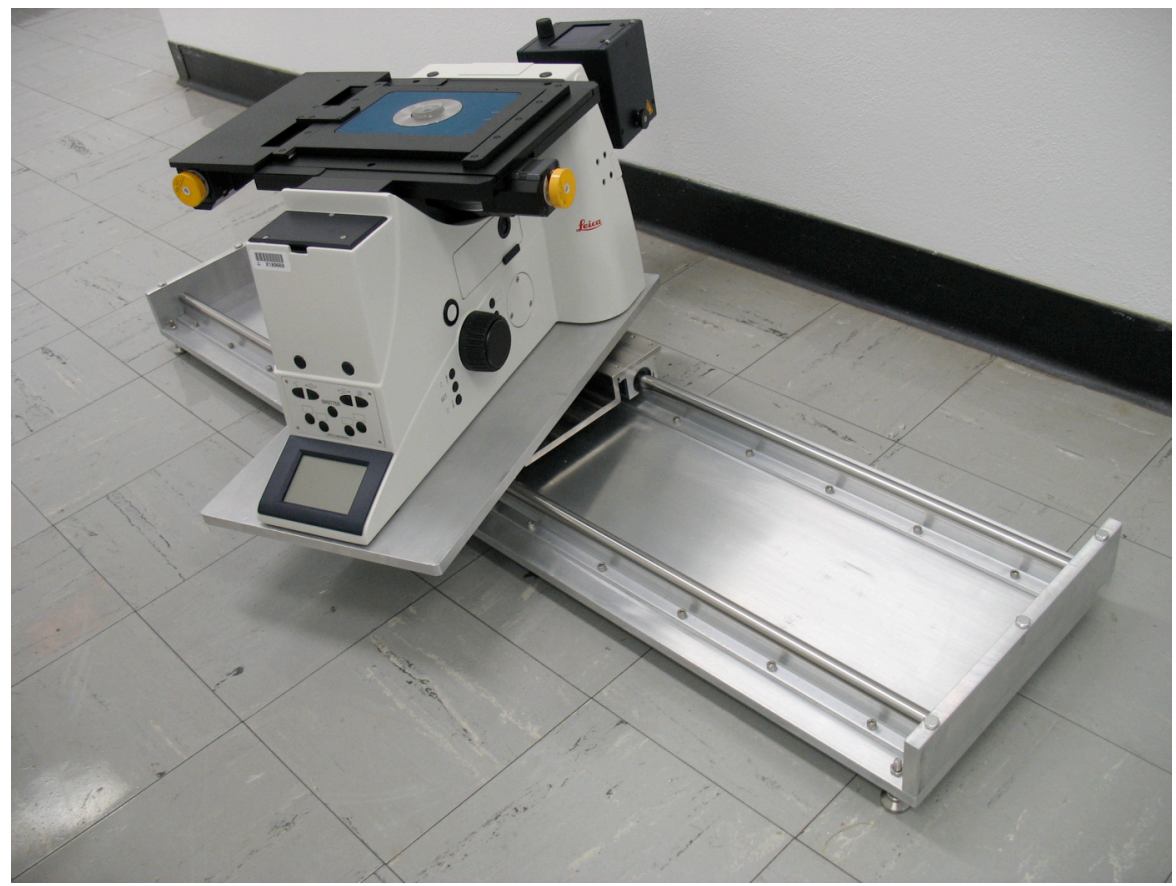

Figure 3. Metallograph on sliding turntable, designed to allow access for maintenance. 


\section{Upgrade Furnace for Accident Heat-up Tests (MPO-70089/SOW-5699)}

\section{Objectives}

The Core Conduction Cooldown Test Facility (CCCTF) was built for the NPR program in the late 1980's to measure fission product release under postulated loss of coolant accident conditions. During the NGNP PIE work, the CCCTF will be used to heat AGR fuel compacts and collect metallic and gaseous fission products released from the fuel, verifying fission product retention behavior of the fuel under simulated accident conditions. The current CCCTF furnace is operational in a helium atmosphere, but the airlock which allows changing the deposition cup during operation is currently not operational, thus metallic fission products can only be collected for the entire furnace operational period rather than periodically examined as is required for programmatic work. The planned upgrade would restore the airlock function and allow the desired deposition cup changing feature. After this upgrade the furnace will be fully operational, including the gas purge system and cold traps along with the control system. This task involves (i) design of the system upgrades, (ii) materials acquisition and fabrication, (iii) installation of the upgraded components and integration into the existing control system, (iv) system testing, (v) modification of existing procedures, and (vi) installation of the system in a shielded cubicle.

\section{FY08 Progress Summary}

The design of the new CCCTF airlock has been completed and sent to the shop for fabrication. The design is a gate valve for sealing and a non-sealing thermal reflector to remove the heat load issues on the gate valve. The cold-finger will be sealed by $\mathrm{O}$ rings and a vacuum/He purging system will accommodate removal and insertion of the deposition cup without interruption of the fuel heating cycle. See Figure 4 and Figure 5 for a diagram of the airlock and its placement on the furnace. Fabrication problems have delayed the completion of the airlock. Some redesign of the lower part of the airlock was necessary because the original material, copper, proved too difficult to weld. The copper component was replaced by aluminum and the joint modified.

In addition, two other changes were made to both improve a cooling problem and accommodate the new airlock. The first was to modify the cold finger mounting configuration to make it less rigid and more self aligning so the entry into the airlock is more reliable. The second was to modify the design of the furnace bottom flange to improve its cooling, especially at the thermocouple seal. This region has been operating at the upper edge of the safe region and the cooling needed to be improved for long term reliability.

\section{Future Activities}

Expected delivery of the airlock is in September and installation will begin as soon as possible after that. Once the installation is complete, the furnace control system will be modified and cold testing conducted. After this phase has been completed, a short term heat up test will be conducted to demonstrate the operation of the system at temperature. 


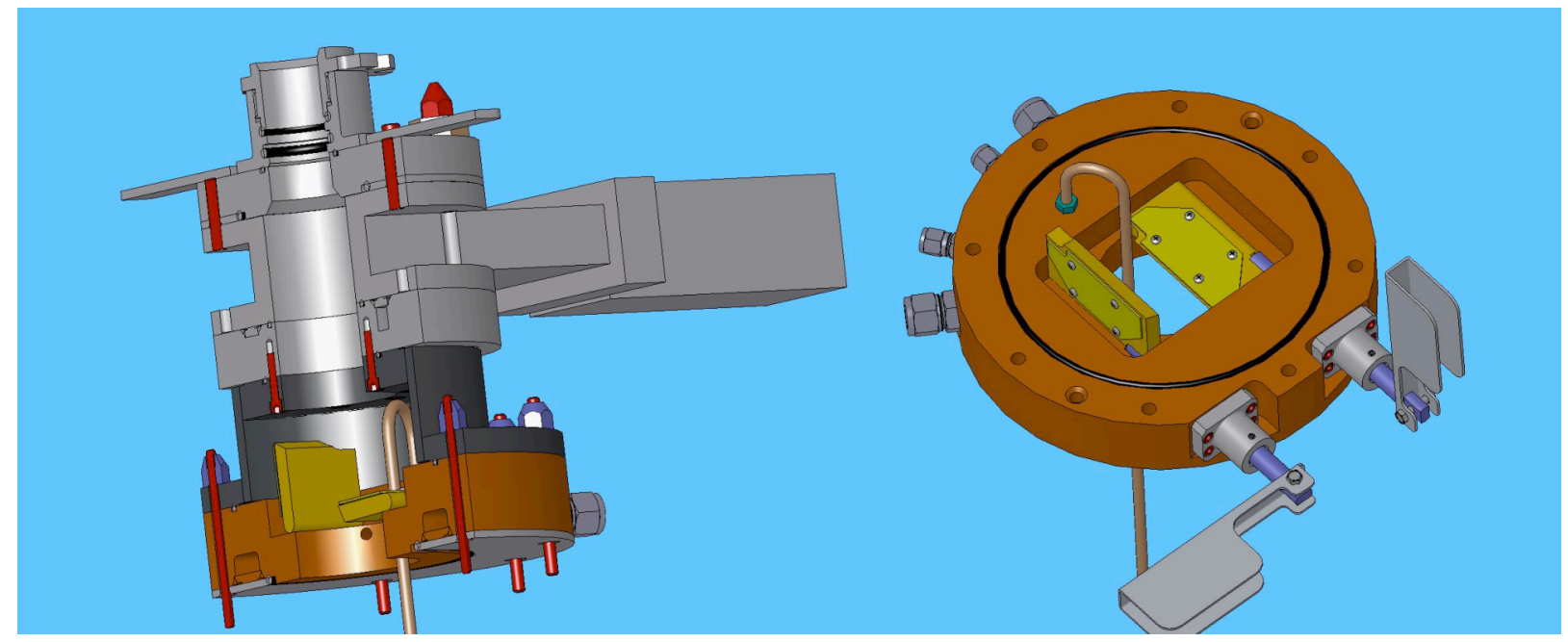

Figure 4. Airlock illustration showing the overall design, gate valve, and thermal shield (thermal shield detail on right).

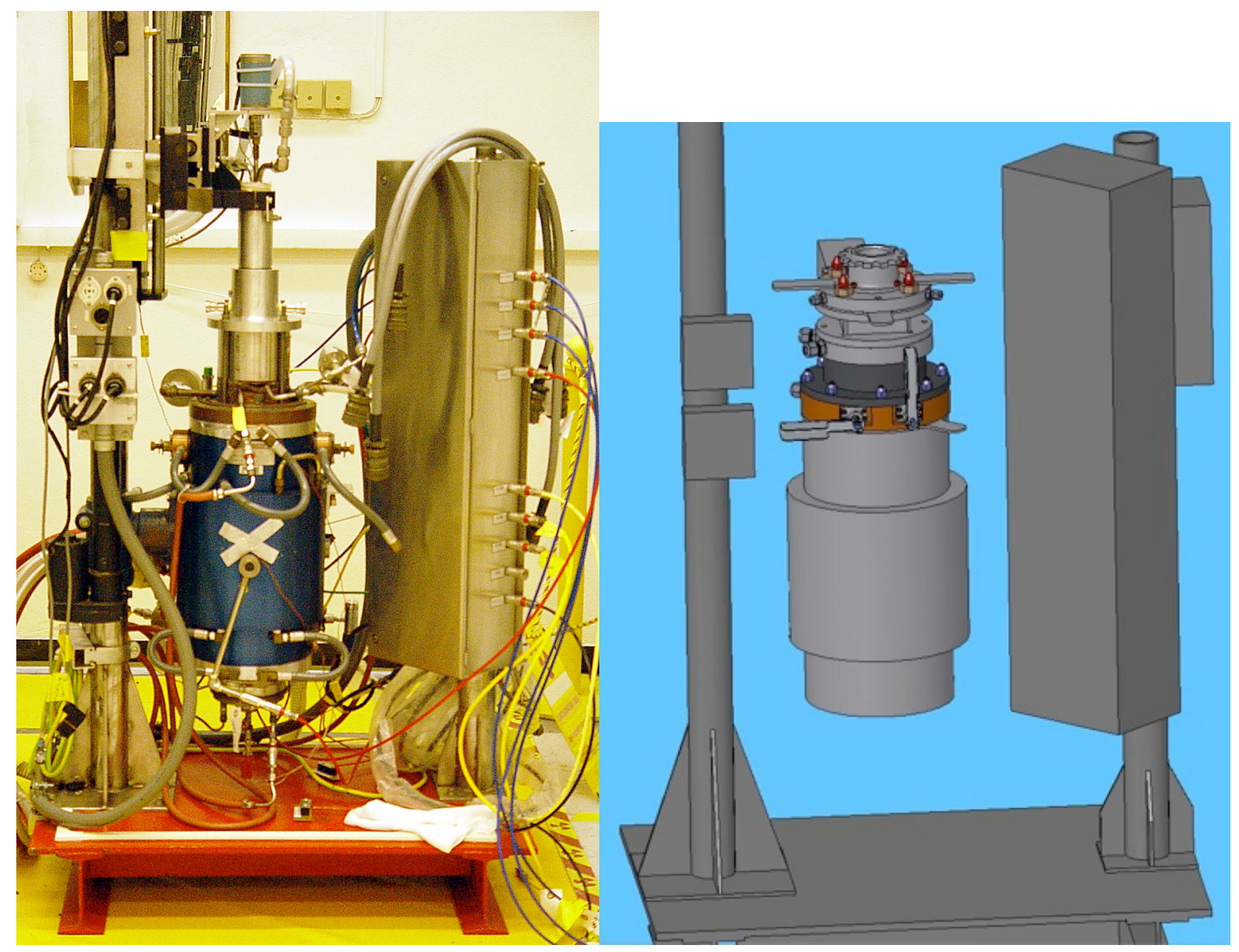

Figure 5. NPR CCCTF furnace (left) and drawing of the new airlock in position on the top of the furnace (right). 


\section{Development of Compact Deconsolidation and Leach-Burn-Leach Methods for Hot Cell Applications (MPO-70090/SOW-5700)}

\section{Objectives}

Fuel deconsolidation and the leach-burn-leach (LBL) technique will be an important part of the irradiated fuel examination work. Two basic options exist for performing deconsolidation/LBL on AGR fuel specimens: (1) implementing the conventional methods, which are currently used for characterization on as-fabricated fuel; or (2) developing a promising microwave digestion technique that could provide significant benefits for in-cell operations, including reduced equipment footprint in-cell, higher sample throughput, and a reduced waste stream.

An early FY08 task was to complete an evaluation of the past results and future potential of using a microwave digestion system to perform the deconsolidation and leaching process on AGR fuel compacts in order to increase sample throughput and reduce waste generation for both the pre- and post-burn leach. Based on the outcome of this study, it was determined that the conventional LBL method would be further developed by the program for hot cell installation. This task included developing modifications to the standard equipment and procedures as necessary to support in-cell operation, purchasing the necessary hardware, testing the modified equipment in a laboratory environment, qualifying procedures, determining the best shielded location at ORNL for installation, and installing the equipment in the hot cells.

\section{FY08 Progress Summary}

A report was distributed at the end of November providing the results of the evaluation of the microwave digestion method. This report presented available data from previous tests, an overview of the system capabilities of commercially available equipment, calculations of the efficiency gains compared to conventional approaches, a list of remaining aspects requiring evaluation, and an analysis of the pros and cons versus traditional LBL methods. The AGR PIE Working Group discussed the findings and concluded that the higher throughput, reduced analysis time, and waste generation advantages using the microwave system were not needed for the PIE application because of the limited number of samples that will be analyzed, as opposed to fuel production QC applications that require a large number of samples to be quickly analyzed in order to meet the statistical criteria of the acceptance tests on a production schedule. The decision was to proceed with development of a conventional method for hot cell application.

A two station wet chemistry test stand; one station for electrolytic deconsolidation and the other for nitric acid reflux leaching was designed. Because hot cell application requires the use of remote manipulators, the conventional pot leach was replaced with the introduction of a Soxhlet extractor for the leaching. The Soxhlet method avoids several difficult handling steps, such as transfer of solid material between vessels, centrifuging and pipetting. Multiple tests were run to evaluate and compare the Soxhlet extractor approach against the existing pot leach method. The Soxhlet method was determined to produce equivalent results. A report was issued describing the Soxhlet extraction method and the results of these evaluation and qualification studies. The extractor operates by condensing vapor from a flask of boiling nitric acid to fill the extraction region where a thimble holding the sample resides. The acid in the extraction region is siphoned back into the bottom flask every 20 minutes (see Figure 6). 

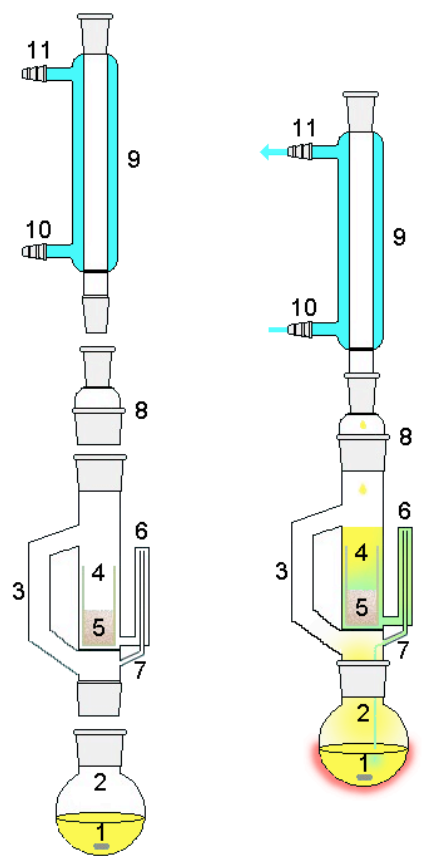

1: Stirrer bar

2: Still pot

3: Distillation path

4: Fritted thimble

5: Solid in thimble

6: Siphon top

7: Siphon exit

8: Expansion adapter

9: Condensor

10: Cooling water in

11: Cooling water out

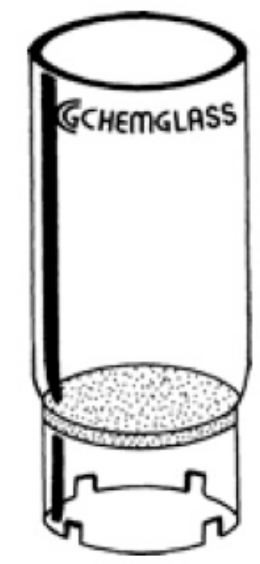

Figure 6. Schematic of LBL station using a Soxhlet extractor with example of fritted thimble (right).

Equipment for the Hot Cell Deconsolidation and LBL system was purchased and assembled. A muffle furnace was modified to move the control electronics outside the hot cell. The hearth for heating the nitric acid also has the controller located outside of the cell. Other electrical feedthroughs into the cell include several thermocouple connections and DC power lines for the deconsolidation electrodes. All these electrical feedthroughs have been designed into a cell penetration plug at the front of the cell. A water chiller will be located in the charging area behind the cell and use existing feedthroughs at the back. Figure 7 shows the completed assembly of the two test stations, which were placed in the hot cell mock-up for final testing and design optimization.

\section{Future Activities}

In August, INL hot cell personnel visited ORNL to become familiar with the equipment design and test procedures and to obtain hands-on experience using hot cell manipulators to handle the deconsolidation and LBL glassware. In the near future, INL will adapt the ORNL test fixture design for their use. A comparative analysis between the two systems is also being considered. In the second half of FY09, the systems will need to be installed in the hotcells in preparation for AGR-1 PIE in 2010. 


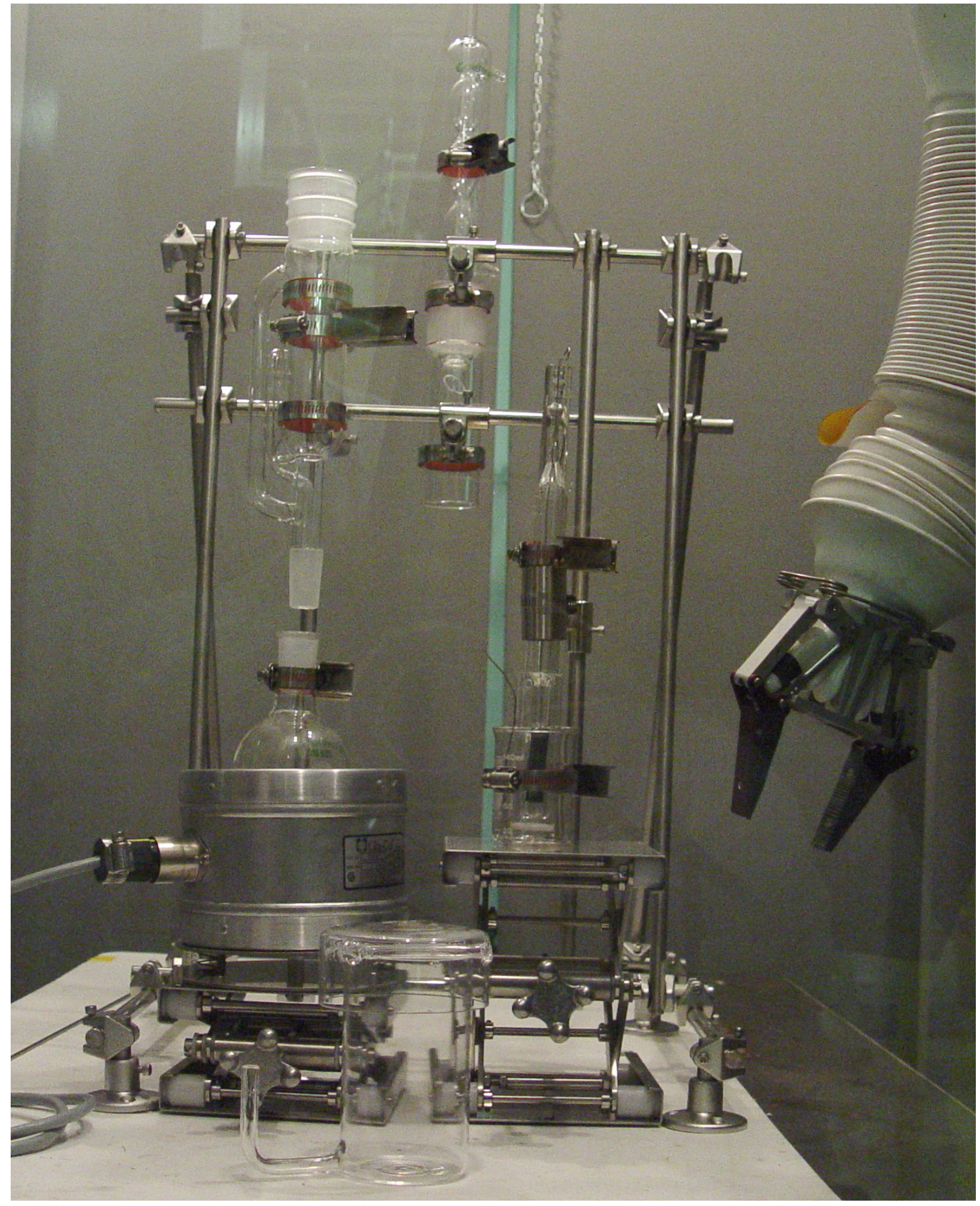

Figure 7. LBL (left) and deconsolidation (right) stations shown in position in the hot cell mock-up. The quartz chamber for placing the sample thimble into the furnace for burn-off is shown in front. 


\section{IMGA and Micromanipulator Upgrades (MPO-78451/SOW-6544)}

\section{Objectives}

Analysis of individual irradiated fuel particles will be a critical activity for the NGNP post irradiation examination. This will include irradiated microsphere gamma analysis (IMGA), in which gamma spectra of individual particles will be analyzed in specialized equipment to quantify the inventories of various fission products in the particles. This will allow the fission product retention characteristics of the particles to be determined. IMGA instrumentation exists at ORNL, but the existing system is in need of upgrades to enable automated operation. Closely related to the IMGA system, and also needed for AGR-1 PIE, is the capability for remote handling, inspection, and sorting of individual irradiated particles. A particle micromanipulator currently resides in the IMGA cubicle at ORNL for this purpose, but several major components are nearing the end of their useful life and upgrades are needed to ensure continued reliable operation.

\section{FY08 Progress Summary}

In late July 2008, funding was received to begin work on a replacement micromanipulator unit and to redesign the IMGA system. Initial work has begun mostly in the areas of design, early component specification and long lead time parts procurement. Particle handling, gamma counting system upgrades, servomotor controls, and hot cell layout are currently being considered.

The conceptual design of the IMGA system is shown in Figure 8. Two particle handling approaches are being considered. The first would allow the handling system to transfer individual particles sealed in vials to and from the gamma counting position. The individual particles would be manually loaded in Wheaton type vials with tapered bottoms. The tapered vials accurately center a particle for counting and prevent any possibility of damaging a particle during handling. The vials can also be labeled to maintain unique particle identification. Handling the vials in the hot cell could be accomplished with vacuum technology. The cap of each vial has a perfect surface for a miniature suction cup to attach to. The vials would be set up in a rotary carousel, with linear (X-Z) actuators to move a vacuum suction cup pick up assembly from the loading/unloading location above the rotary tray to the shielded counting location in front of the detector port in the hot cell wall. In the counting location the vial can be deposited in a holder for the long counting times necessary to obtain data on isotopes such as ${ }^{110 \mathrm{~m}} \mathrm{Ag}$. After a count has completed, the control system will automatically store the data, return the vial to its place in the rotary tray, set up the next vial for counting, and initiate the next count. This process would continue 24 hours a day 7 days a week until all the particles are counted. The only intervention required by the operator would be to input an appropriate count time and to change the vials at the beginning of each run.

For the second particle handling approach, the particle sorting capability of the system would be accomplished using modern computer controlled vacuum ejector technology. In contrast to the old system that relied on a complicated rotating drum assembly with extremely tight mechanical tolerances between the particle hopper and the drum, the new system would utilize a "floating hypodermic needle" sized to the particular fuel to be examined. The needle would act as a 
computer controlled micro-manipulator which would select a single particle from an input batch of particles, transport the particle to the internally shielded counting position, and then return the particle to a sorter/collector assembly where it would be dropped into an appropriate vial based on its fission product retention characteristics. This system would utilize the same hardware as the vial handling design only replacing the suction cup assembly with the floating needle assembly. Note that one or more of the vial positions in the collector assembly would act as hoppers for input particles and the remaining vials would act as receptacles for the particles after counting. This design feature eliminates the need for a third axis of translation.

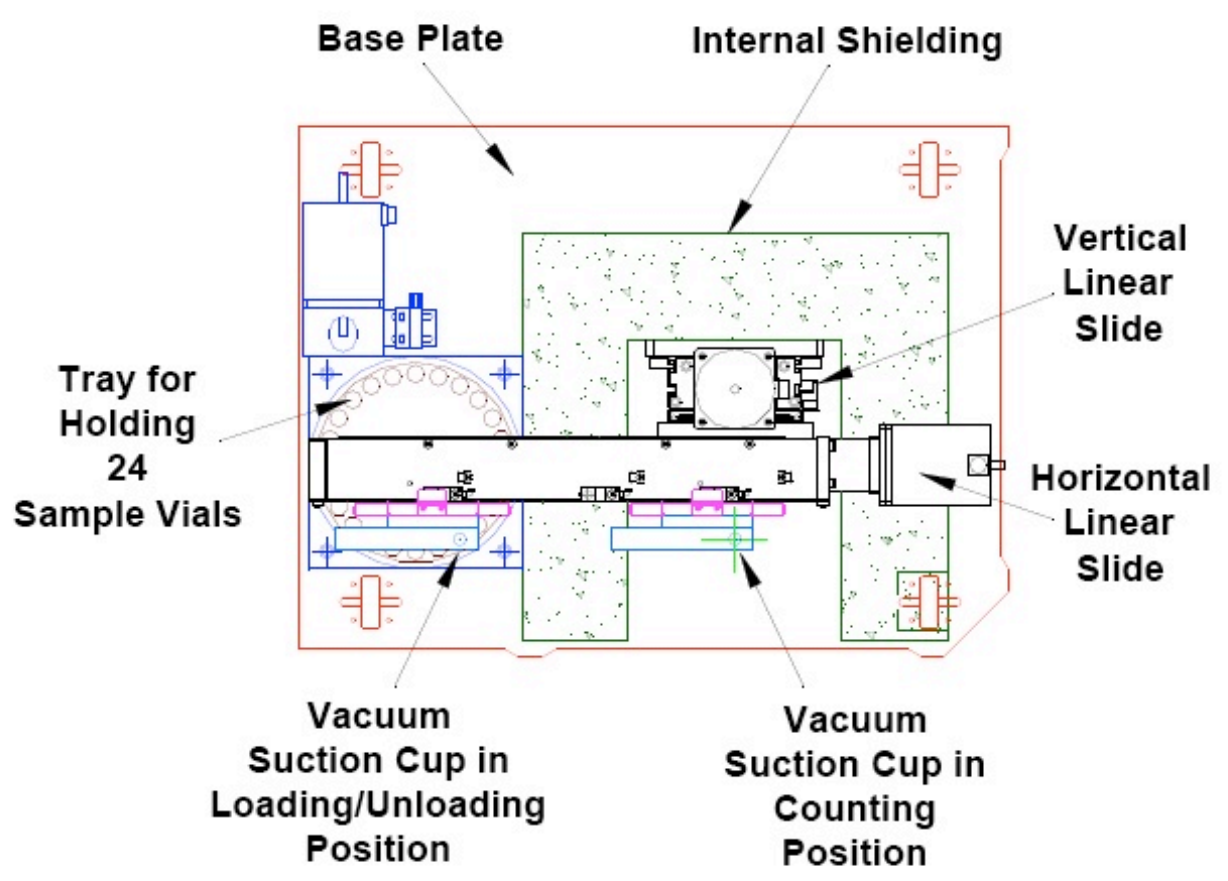

Figure 8. Conceptual design of the new IMGA system, viewed from the top of hot cell.

Figure 9 shows the SMC vacuum ejector module with a prototype floating hypodermic needle. The test objects shown are an inert AGR particle and a $1350 \mu \mathrm{m}$ diameter stainless steel calibration sphere. Both objects were easily captured by the needle from a large batch of like particles. Proper selection of needle size eliminated initial problems of multiple particles being captured at the same time. The vacuum sensing output signal from the module gave a consistent 0.20 volt change when an object was captured on the needle. This feature provides a significant advantage over previous IMGA systems that relied on the gamma spectrometer to confirm that a particle was successfully transferred.

The existing particle micromanipulator at ORNL includes a through-wall stereo microscope with an articulated vacuum needle (micromanipulator) and a 3-axis motor stage. The stereo microscope, micromanipulator, and stereo-stage work together to allow the operator to sort through trays of material, examine individual particles, and select individual particles for special 
testing or analysis. Design options are currently being considered to replace the old and failing micromanipulator.

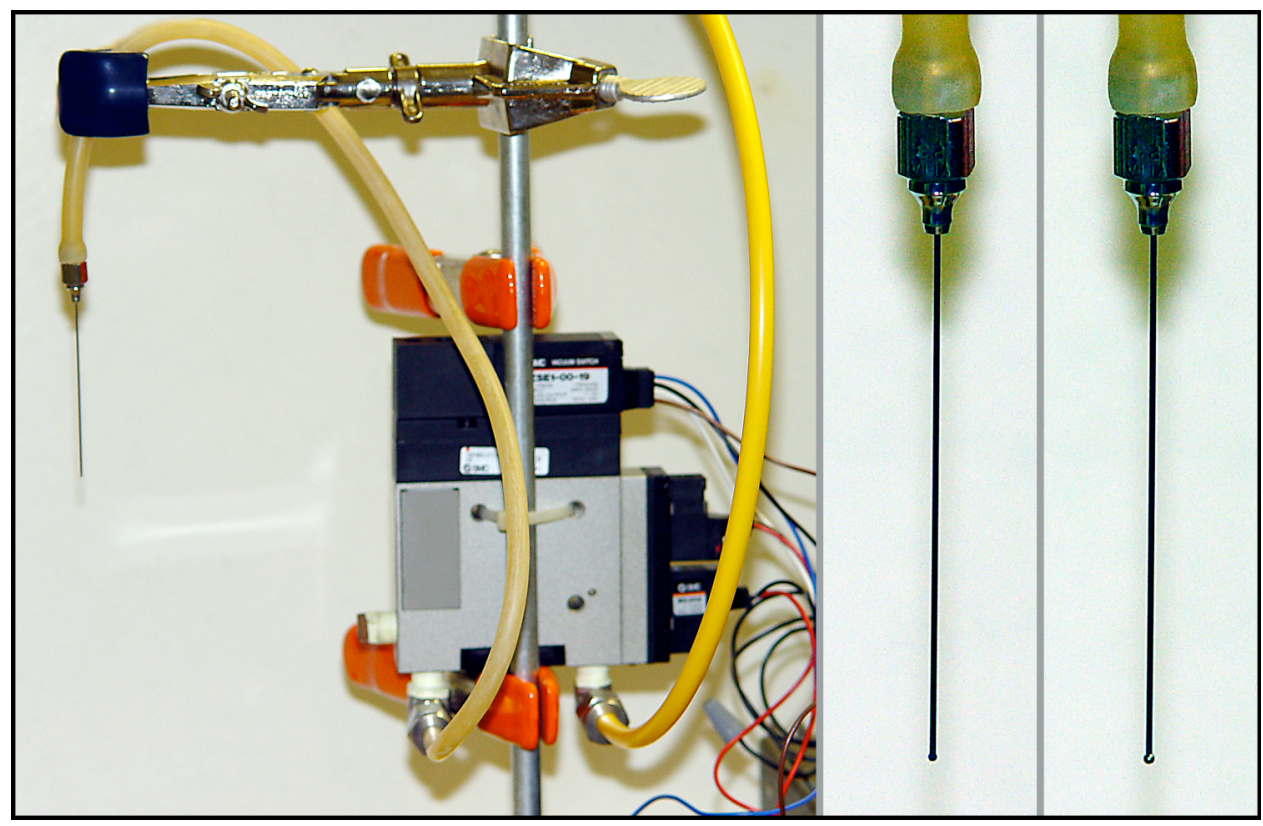

Figure 9. Bench top testing of the SMC vacuum ejector module and floating needle.

\section{Future Activities}

An appropriate vacuum needle sensor and control system has been identified and additional parts will be ordered in September. Upgrades to the gamma counting system are also on order. Final design, acquisition, assembly and bench testing of the new systems is planned for FY09. Installation into the hotcell will need to occur in late FY09 or early FY10 to be ready for analysis of particles deconsolidated from AGR-1 irradiated compacts. 